Journal of Advanced Research in Fluid Mechanics and Thermal Sciences

\title{
A Review of Heat Stress Impact Towards Construction Workers Productivities and Health Based on Several Heat Stress Model
}

\author{
Che Mohammad Nizam ${ }^{1,2, *}$, Ahmad Rasdan Ismail ${ }^{2}$, Norlini Husshin ${ }^{3}$ \\ Department of Occupational Safety and Health, Menara TJB, Jalan Dato' Syed Mohd Mufti, 80534, Johor Bahru, Johor, Malaysia \\ 2 Faculty of Creative Technology \& Heritage, University Malaysia Kelantan, 16310 Bachok, Kelantan, Malaysia \\ 3 Department of Mechanical Engineering, Politeknik Ibrahim Sultan, 81700, Pasir Gudang, Johor, Malaysia
}

\section{ARTICLE INFO}

\section{Article history:}

Received 11 April 2021

Received in revised form 10 July 2021

Accepted 15 July 2021

Available online 4 August 2021

\section{Keywords:}

Temperature; WBGT; Heat Stress Model; Heat Stress Index

\section{ABSTRACT}

\begin{abstract}
Global average temperature has increase $0.2^{\circ} \mathrm{C}$ in the past 10 years. Furthermore, several studies have predicted that the temperature will keep increasing due to lack of effort in restricting carbon emission. Therefore, the objective of this review is to examine the impact of heat stress towards construction workers productivities and health and also assess the risk of exposure. Literature review was done through scoping method on major journal database and Google Scholar. Major heat stress models are Heat Index, Wet bulb globe temperature and Thermal Work Limit. On the other hands, there are more complex heat stress model that incorporate complex data measurement, such as Predicted Heat Strain endorsed by ISO 7933:2004. Several studies have been conducted based on these heat stress model. Findings of these studies shown that hot and humid countries, such India, China, Hong Kong, Thailand, Japan, Iran, Saudi Arabia, Egypt, United Arab Emirates, and Australia WBGT level are at least $28^{\circ} \mathrm{C}$, which is beyond safe level for medium and heavy construction work. Productivities were estimated to decline up to $2 \%$ for every $1^{\circ} \mathrm{C}$ increase in temperature above safe WBGT level. In extremely high temperature environment, productivities can decrease in the range of $48 \%-94 \%$. Heat stress negative side effect on health include minor heat related illness such as thirst, fatigue, headache, dehydration, vertigo, nausea and muscle pain.
\end{abstract}

\section{Introduction}

Global average temperature is increasing 0.2 Celsius for every 10 years since 1980 [1]. In fact, the increase in temperature during the last three decades overcome the cooling period aftereffects from 1940 's to 1970's [2]. Therefore, the global temperature is back on the upward trend since 1980's and few studies have forecast that it will keep rising for few more decades, unless there are drastic measure to significantly control global warming emission $[3,4]$. In addition, the prolonged excessive warm weather combined with high humidity level have created series of heat wave events all over the world, for example in France in 2003 [5] and South Korea in 2018 [6]. In both of these heatwave

\footnotetext{
* Corresponding author.

E-mail address: chenizam@mohr.gov.my
}

https://doi.org/10.37934/arfmts.85.1.161168 
events, huge number of deaths have been recorded. Malaysia is also affected by global warming and it have cause serious climate change issues, including huge production losses for paddy and oil palm industries [7].

The side effect of rising temperature is prominent towards construction industry since most of the work are done outdoor [8]. Construction workers are directly affected by sunlight at the work site for most of their working hours, thus, face huge risk of heat related illness (HRI) and decrease in productivities [9]. Furthermore, the lack of shadings area, work-rest regulation, Personal Protective Equipment (PPE) and constant provision of water have made it hard for the worker to protect themselves from the scorching heat.

Heat stress is one of critical hazard that construction workers face due to prolonged heat exposure, where the body failed to regulate core temperature [10]. This is because there is a limit to how much heat a body can tolerate before it becoming unbearable. Exposure to environmental wetbulb temperature $\left(T_{w}\right)$ of $35^{\circ} \mathrm{Celsius}$ and above could led to hyperthermia since its impossible for the body to dissipate metabolic heat anymore [11]. Once body temperature reaches $39.4^{\circ} \mathrm{Celsius,}$, body organ will start to dysfunction and this will impair the individual physical and mental capacities [12].

From productivities perspective, construction workers performances are expected to decline when they face heat stress. It is estimated for workers productivities to decline up to $50 \%$ when the workplace temperature reaches $33^{\circ}$ to $34^{\circ}$ Celsius [13]. The situation become worse at $39^{\circ} \mathrm{Celsius}$ where body function starts to deteriorate and performances critically plummet [14]. In addition, heat stress that is not treated could lead to heatstroke which is life threatening [15].

The objective of this literature review is to examine the impact of heat stress towards construction workers all around the world. The review focused on heat stress index and heat stress model created to assess heat stress impact. In addition, this study examines heat stress influence on workers from the perspective of financial lost, reduce in productivities and decline in performances. On the other hands, the impact of heat stress towards construction workers health and its side effect are also analysed. Finally, the effectiveness of current control mechanism implemented for heat stress will be critically reviewed. The significance of this review is increasing awareness on the impact of heat stress towards construction workers in hot climate countries, including Malaysia

\section{Methodology}

This study uses general scoping review method to search and identify papers, journals and articles relevant to the main topic. The databases mainly referred were Emerald, PubMed, MDPI, AkedemiaBaru and Science Direct. On top of that searches were also done through Google Scholar. The key words used to search are "heat stress", "construction workers", "heat stress model", "productivities", "health" and "risk". For heat stress impact review sections, the search results must include "heat stress", "construction workers", "heat stress model" and its impact towards either "productivities", "health" or "risk'. Only English materials were accepted and no papers from NGO were used.

\section{Results}

\subsection{Heat Stress Model}

Heat stress is known to have negative impact on workers comfort at the workplace [16]. There are six environment factors that contribute heat stress towards an individual, namely; air temperature, humidity, radiant heat, wind speed, metabolic heat, and "clothing effect" [17]. To accurately evaluate heat stress impact on worker, several heat stress model have been developed. 
Chan et al., [18] heat stress model determines the impact of heat stress by combining heat index with physiological data, such as respiratory rate, hear rate, ventilation, oxygen uptake, and fatigue level. Moreover, personalized factor such as body fat percentage, smoking habits, drinking habits and age are also included.

Nonetheless, the model only includes two environmental factors for Heat Index, which are temperature and relative humidity. Therefore, a more robust heat index was developed to accurately represent environmental factors and it was named Wet bulb globe temperature index (WBGT). The main component WBGT are natural wet bulb to measure humidity, globe thermometer temperature to measure solar radiation and dry bulb temperature to measure air temperature [19]. Heat Index evolved further with Thermal Work Limit (TWL) that include two more environmental factors besides the one recorded by WBGT, which are wind speed and atmospheric pressure [20].

International Standard (ISO) 7933:2004 recommended a far more complex heat stress model named Predicted Heat Strain (PHS) which include two more thermal factors, sweat rate and rectal temperature [21]. PHS model can accurately calculate duration limit of exposure for construction workers, however, it requires complex data collection process. Another well-known heat stress models are Predicted Mean Vote (PMV) which incorporate people vote on a 7 point scale and Predicted Percentage Dissatisfied (PPD) which include values from people that is not satisfied with the thermal environment [22]. Both of these models include people vote as factor for determining heat stress level.

\subsection{Heat Stress Impact on Worker Productivities}

Heat stress had been proven to have huge influences on Construction Workers Productivities (CWP). Hot and humid country such as India withstands $2 \%$ productivity losses for every $1^{\circ}$ Celsius increase in temperature due to declining worker performances [23]. Kjellstorm [24] support the statement by stating hot and humid regions such as South East Asia and Eastern Sub-Saharan Africa countries going to suffer the huge productivities lost compared to much colder region.

To examine and review the impact of heat stress towards construction workers productivities, several studies which utilizes Heat Stress Model as research method have been chosen. Venugopal et al., [25] findings shown that construction workers are exposed to temperature beyond the safe TWL level for moderate and heavy work. In addition, $44 \%$ construction workers that participated in the study reported that they experience productivity losses for moderate and heavy workload. Chinnadurai [26] PMV analysis findings indicated workers suffer $18 \%$ to $35 \%$ lost in productivities when working beyond TLV of $28^{\circ} \mathrm{Celsius}$ at either medium or heavy workload. PMV analysis used in this study follow ISO 7730 and ISO 8996 guidelines. Sett and Sahu [27] study the impact of extreme summer temperature towards female construction worker in India. Finding of the study reflected the female workers are working at extreme temperature of $39.8 \pm 4.81^{\circ} \mathrm{C}$ and WBGT range of $26.9^{\circ} \mathrm{C}$ to $30.74^{\circ} \mathrm{C}$. Furthermore, productivities were recorded to plummet by $2 \%$ for every $1{ }^{\circ} \mathrm{C}$ increased. Kuklane et al., experiment in a simulation chamber predicted $16 \%$ to $36 \%$ productivities lost through PHS model for every $2^{\circ} \mathrm{C}$ increase above air temperature of $35^{\circ} \mathrm{C}$ [28].

Several studies for construction workers in Hong Kong show declined in productivities for every $1^{\circ} \mathrm{C}$ increase in WBGT beyond $31^{\circ} \mathrm{C}$ [29-31] At this point, workers start to slowed down and take breaks to cooldown body temperature by either smoking, drinking, go to toilet or using smartphone. Construction workers for Kiln Brick in Iran experience average WBGT of $39.48^{\circ} \mathrm{Celisius}$ for the entire shift and it led to productivities lost in the range of $48 \%$ to $94 \%$ [32]. The wide range of productivity lost is due to different temperature level during working hours, where maximum lost happen at peak WBGT. The summary of all heat stress impact on productivities is shown in Table 1. 


\section{Table 1}

Summary of Heat Stress Impact Towards Workers Productivities

\begin{tabular}{|c|c|c|c|c|}
\hline Author & Country & Heat Index & Temperature & Productivity Impacts \\
\hline $\begin{array}{l}\text { Venugopal et al., } \\
\text { (2016) }\end{array}$ & India & $\begin{array}{l}\text { WBGT } \\
\text { TWL }\end{array}$ & $\begin{array}{l}\text { WBGT }=28.7^{\circ} \mathrm{C} \pm 1.6 \\
\text { Dry Bulb }=34.5^{\circ} \mathrm{C}\end{array}$ & $\begin{array}{l}44 \% \text { workers report they } \\
\text { experience productivity losses. }\end{array}$ \\
\hline $\begin{array}{l}\text { Chinnadurai et al., } \\
\text { (2016) }\end{array}$ & India & $\begin{array}{l}\text { WBGT } \\
\text { PMV }\end{array}$ & WBGT $=28^{\circ} \mathrm{C}$ & $18 \%-35 \%$ productivities lost. \\
\hline $\begin{array}{l}\text { Sett and Sahu } \\
(2014)\end{array}$ & India & WBGT & $\begin{array}{l}\text { WBGT }=26.9^{\circ} \mathrm{C} \text { to } \\
30.74^{\circ} \mathrm{C} \\
\text { Dry Bulb }=39.8 \pm 4.81^{\circ} \mathrm{C}\end{array}$ & $\begin{array}{l}2 \% \text { productivities lost for every } \\
1{ }^{\circ} \mathrm{C} \text { increased. }\end{array}$ \\
\hline Kuklane et al., (2014) & India & $\begin{array}{l}\text { WBGT } \\
\text { PHS }\end{array}$ & $\begin{array}{l}\text { Air Temperature }=35^{\circ} \mathrm{C} \\
\text { Globe Temperature }= \\
38^{\circ} \mathrm{C}\end{array}$ & $\begin{array}{l}16 \% \text { to } 36 \% \text { productivity lost } \\
\text { for every } 2^{\circ} \mathrm{C} \text { increase in } \\
\text { temperature }\end{array}$ \\
\hline $\begin{array}{l}\text { Yi et al., } \\
\text { (2017) }\end{array}$ & Hong Kong & WBGT & $\begin{array}{l}\text { WBGT }=31.87^{\circ} \mathrm{C} \pm 2.03 \\
\text { from } \\
2.00 \mathrm{pm} \text { to } 3.00 \mathrm{pm}\end{array}$ & $\begin{array}{l}\text { Direct Work Time (DWT) } \\
\text { reduced by } 0.33 \% \text { for every } \\
1^{\circ} \mathrm{C} \text { increased in WBGT. }\end{array}$ \\
\hline $\begin{array}{l}\text { Yang and Chan } \\
\text { (2017) }\end{array}$ & Hong Kong & WBGT & WBGT $=32.06 \pm 1.73^{\circ} \mathrm{C}$ & $\begin{array}{l}\text { Workload increase } 10 \% \text { of } \\
\text { relative heart rate for every } \\
1^{\circ} \mathrm{C} \text { increased }\end{array}$ \\
\hline $\begin{array}{l}\text { Li et al., } \\
\text { (2016) }\end{array}$ & China & WBGT & WBGT $=32^{\circ} \mathrm{C}$ & $\begin{array}{l}\text { Direct Work Time (DWT) } \\
\text { reduced by } 0.57 \% \text { for every } \\
1^{\circ} \mathrm{C} \text { increased in WBGT. }\end{array}$ \\
\hline $\begin{array}{l}\text { Hajizadeh et al., } \\
\text { (2014) }\end{array}$ & Iran & WBGT & $\begin{array}{l}\text { WBGT }=39.48 \pm 8.2^{\circ} \mathrm{C} \\
\text { (Klin Workers only) }\end{array}$ & $48 \%$ to $94 \%$ productivities lost. \\
\hline
\end{tabular}

\subsection{Heat Stress Impact on Worker Health}

Heat Stress have been reported to give adverse impact on construction workers health [33]. Most common side effect of heat stress includes intense thirst, fatigue, vertigo, nausea and headache [34 -37]. Furthermore, high temperature combined with bad working posture and heavy workload significantly increase the risk of muscle fatigue [38]. At WBGT above $32^{\circ} \mathrm{C}$, construction worker faces risk of high Urine Specific Gravity, where it can led to severe hypohydrated [39-41]. In addition, prolonged exposure to WBGT beyond the safety threshold could also increase the risk of high heart rate and hypertension [42,43]. Physiology factors such as oxygen uptake and heart rate also increased significantly when the level of air temperature and relative humidity increased [44]. Construction workers also start to show Heat Related Symptom after working long hours, such as losing appetite and becoming more impatience [45]. The summary of all heat stress impact on worker health is shown in Table 2. 


\section{Table 2}

Summary of Heat Stress Impact Towards Workers Health

\begin{tabular}{|c|c|c|c|c|}
\hline Author & Country & Heat Index & Temperature & Health Impacts \\
\hline $\begin{array}{l}\text { Al-Bouwarthan et al., } \\
\text { (2019) }\end{array}$ & Saudi Arabia & $\begin{array}{l}\text { HI } \\
\text { ACGIH TLV } \\
\text { WBGT }\end{array}$ & WBGT $=31-33^{\circ} \mathrm{C}$ & $\begin{array}{l}\text { High level of heat stress risk } \\
\text { ( } 75 \% \text { ) due to WBGT exceeds } \\
\text { TLV for both medium and } \\
\text { heavy workload starting from } \\
7 \text { am. }\end{array}$ \\
\hline $\begin{array}{l}\text { Dutta et al., } \\
\text { (2015) }\end{array}$ & India & WBGT & WBGT $=32.4^{\circ} \mathrm{C} \pm 1.10$ & $\begin{array}{l}\text { 59\% of workers reported heat } \\
\text { related symptoms } \\
\text { - Intense thirst } \\
\text { - Fatigue } \\
\text { - Headache }\end{array}$ \\
\hline Maiti (2008) & India & $\begin{array}{l}\text { WBGT } \\
\text { TLV }\end{array}$ & WBGT $=30.26 \pm 1.52^{\circ} \mathrm{C}$ & $\begin{array}{l}\text { Workers experienced extreme } \\
\text { muscular fatigue }\end{array}$ \\
\hline Bates et al., (2008) & $\begin{array}{l}\text { United Arab } \\
\text { Emirates }\end{array}$ & $\begin{array}{l}\text { WBGT } \\
\text { TWL }\end{array}$ & $\begin{array}{l}\text { WBGT }=28.6^{\circ} \mathrm{C} \\
\text { from } 12 \text { noon to } 2 \mathrm{pm}\end{array}$ & Fatigue and Dehydration \\
\hline $\begin{array}{l}\text { El Shafei et al., } \\
(2018)\end{array}$ & Egypt & WBGT & WBGT $=30^{\circ} \mathrm{C}$ & $\begin{array}{l}\text { Heat illness } \\
\text { - } \quad \text { Dizziness } \\
\text { - } \text { Muscle pain } \\
\text { - } \\
\text { Dehydration }\end{array}$ \\
\hline Zhao et al., (2009) & $\begin{array}{l}\text { China } \\
\text { (Simulation } \\
\text { Chamber) }\end{array}$ & WBGT & WBGT $=34^{\circ} \mathrm{C}$ & $\begin{array}{l}\text { Heat Stress Disorder Symptom } \\
\text { reported } \\
\text { - Vertigo } \\
\text { - Nausea }\end{array}$ \\
\hline $\begin{array}{l}\text { Montazer et al., } \\
(2013)\end{array}$ & Iran & $\begin{array}{l}\text { WBGT } \\
\text { TWL }\end{array}$ & $\begin{array}{l}\text { WBGT }=32^{\circ} \mathrm{C} \\
\mathrm{TWL}=144 \pm 9.8 \mathrm{~W} / \mathrm{m} 2\end{array}$ & $\begin{array}{l}\text { Urine Specific Gravity is } \\
1.026 \pm 0.005 . \\
\text { - Severely } \\
\text { hypohydrated } \\
\text { - Increased risk of heat } \\
\text { illness }\end{array}$ \\
\hline Farshad et al., (2104) & Iran & $\begin{array}{l}\text { WBGT } \\
\text { TWL }\end{array}$ & $\begin{array}{l}\text { WBGT }=27.5 \pm 1.2^{\circ} \mathrm{C} \\
\mathrm{TWL}=144 \pm 9.8 \mathrm{~W} / \mathrm{m} 2\end{array}$ & $\begin{array}{l}\text { Urine Specific Gravity is } \\
1.0273 \\
\text { - Dehydrated } \\
\text { - Moderate heat stress }\end{array}$ \\
\hline $\begin{array}{l}\text { Brake and Bates } \\
(2003)\end{array}$ & Australia & $\begin{array}{l}\text { WBGT } \\
\text { TWL }\end{array}$ & WBGT $=30.9^{\circ} \mathrm{C}$ & $\begin{array}{l}\text { Urine Specific Gravity is } \\
1.0254 \\
\text { - Severely } \\
\\
\text { hypohydrated }\end{array}$ \\
\hline $\begin{array}{l}\text { Morioka et al., } \\
(2006)\end{array}$ & Japan & WBGT & WBGT $=24^{\circ} \mathrm{C}$ to $34^{\circ} \mathrm{C}$ & $\begin{array}{l}\text { Severe increase in heart rate } \\
\text { and hypertension }\end{array}$ \\
\hline $\begin{array}{l}\text { Inaba and Mirbod } \\
\text { (2007) }\end{array}$ & Japan & WBGT & WBGT $=28.1^{\circ} \mathrm{C}$ to $32^{\circ} \mathrm{C}$ & $\begin{array}{c}\text { Heat Related Symptom } \\
\text { - } \text { Appetite Lost } \\
\text { - } \\
\text { - } \\
\text { Patience Lost } \\
\text { Impatience }\end{array}$ \\
\hline Yoopat et al., (2002) & Thailand & WBGT & WBGT $=29.2^{\circ} \mathrm{C}$ to $34.2^{\circ} \mathrm{C}$ & $\begin{array}{l}\text { Increase in cardiovascular load } \\
\text { up to } 69 \%\end{array}$ \\
\hline
\end{tabular}

\section{Conclusions}

The article review covered several studies and field experiments conducted on hot and humid countries, such as India, China, Hong Kong, Thailand, Japan, Iran, Saudi Arabia, Egypt, United Arab Emirates, and Australia. All of the studies used WBGT as main index and measurements of environmental factors. WBGT results for all studies shown temperature of $28^{\circ} \mathrm{C}$ and higher which is 
not safe for construction works, either at medium or heavy workload. On top of that, several studies have shown high dry bulb temperature up to $39^{\circ} \mathrm{C}$ which on its own is a huge risk for prolonged exposure.

Productivities have also shown to decline for all studies. Highest loss was recorded by Hajizadeh et al., study which also record highest WBGT of $39.48 \pm 8.2^{\circ} \mathrm{C}$. Lower production loss range was recorded in Chinnadurai et al., study, however, the WBGT recorded is also lower. On the other hands, Yi et al., and Li et al., studies both recorded $0.33 \%$ to $0.57 \%$ decrease in work time when WBGT increase. Sett and Sahu studies record higher ratio with $2 \%$ loss for each $1^{\circ} \mathrm{C}$ increased and this is explained by high dry bulb temperature that reach $39.8^{\circ} \mathrm{C}$.

Heat stress negative side effect on health include minor heat related illness such as thirst, fatigue, headache, dehydration, vertigo, nausea and muscle pain. In addition, there are also cases that shown heat stress increase heart rate and also blood pressure for workers that have hypertension disease. Changed in mood was also reported due to heat stress, where workers become more impatience and start to lost appetite.

\section{Acknowledgement}

We want to express our deepest gratitude to all individual involved in this study, either directly or indirectly. We also thank our supervisor in guiding us throughout the project, University Malaysia Kelantan, Department of Occupational Safety and Health (DOSH), Johor State and Politeknik Ibrahim Sultan, Johor.

\section{References}

[1] Hansen, J., M. Sato, R. Ruedy, K. Lo, D. W. Lea, and M. Medina-Elizade. "Proc. of the National Academy of Sciences." (2006). https://doi.org/10.1073/pnas.0606291103

[2] Andronova, Natalia G., and Michael E. Schlesinger. "Causes of global temperature changes during the 19th and 20th centuries." Geophysical Research Letters 27, no. 14 (2000): 2137-2140. https://doi.org/10.1029/2000GL006109

[3] Stott, Peter A., John FB Mitchell, Myles R. Allen, Thomas L. Delworth, Jonathan M. Gregory, Gerald A. Meehl, and Benjamin D. Santer. "Observational constraints on past attributable warming and predictions of future global warming." Journal of Climate 19, no. 13 (2006): 3055-3069. https://doi.org/10.1175/JCLI3802.1

[4] Shiogama, H., D. Stone, S. Emori, K. Takahashi, S. Mori, A. Maeda, Y. Ishizaki, and M. R. Allen. "Predicting future uncertainty constraints on global warming projections." Scientific reports 6, no. 1 (2016): 1-7. https://doi.org/10.1038/srep18903

[5] Poumadere, Marc, Claire Mays, Sophie Le Mer, and Russell Blong. "The 2003 heat wave in France: dangerous climate change here and now." Risk Analysis: an International Journal 25, no. 6 (2005): 1483-1494. https://doi.org/10.1111/i.1539-6924.2005.00694.x

[6] Min, Seung-Ki, Yeon-Hee Kim, Sang-Min Lee, Sarah Sparrow, Sihan Li, Fraser C. Lott, and Peter A. Stott. "Quantifying human impact on the 2018 summer longest heat wave in South Korea." Bulletin of the American Meteorological Society 101, no. 1 (2020). https://doi.org/10.1175/BAMS-D-19-0151.1

[7] Vaghefi, N., Shamsudin, M.N., Makmom, A. and Bagheri, M., 2011. The economic impacts of climate change on the rice production in Malaysia. International Journal of Agricultural Research,6(1), pp.67-74. https://doi.org/10.3923/ijar.2011.67.74

[8] Acharya, Payel, Bethany Boggess, and Kai Zhang. "Assessing heat stress and health among construction workers in a changing climate: a review." International journal of environmental research and public health 15, no. 2 (2018): 247. https://doi.org/10.3390/ijerph15020247

[9] Lugo-Amador, Nannette M., Todd Rothenhaus, and Peter Moyer. "Heat-related illness." Emergency medicine clinics of North America 22, no. 2 (2004): 315-27. https://doi.org/10.1016/j.emc.2004.01.004

[10] Epstein, Yoram, and Daniel S. Moran. "Thermal comfort and the heat stress indices." Industrial health 44, no. 3 (2006): 388-398. https://doi.org/10.2486/indhealth.44.388

[11] Sherwood, Steven C., and Matthew Huber. "An adaptability limit to climate change due to heat stress." Proceedings of the National Academy of Sciences 107, no. 21 (2010): 9552-9555. https://doi.org/10.1073/pnas.0913352107

[12] Dematte, Jane E., Karen O'Mara, Jennifer Buescher, Cynthia G. Whitney, Sean Forsythe, Turi McNamee, Raghavendra B. Adiga, and I. Maurice Ndukwu. "Near-fatal heat stroke during the 1995 heat wave in 
Chicago." Annals of internal medicine 129, no. 3 (1998): 173-181. https://doi.org/10.7326/0003-4819-129-3199808010-00001

[13] International Labour Office (ILO). "Working on a warmer planet: The impact of heat stress on labour productivity and decent work." (2019).

[14] Krishnamurthy, Manikandan, Paramesh Ramalingam, Kumaravel Perumal, Latha Perumal Kamalakannan, Jeremiah Chinnadurai, Rekha Shanmugam, Krishnan Srinivasan, and Vidhya Venugopal. "Occupational heat stress impacts on health and productivity in a steel industry in Southern India." Safety and health at work 8, no. 1 (2017): 99-104. https://doi.org/10.1016/i.shaw.2016.08.005

[15] Lundgren, Karin, Kalev Kuklane, Chuansi Gao, and Ingvar Holmer. "Effects of heat stress on working populations when facing climate change." Industrial health 51, no. 1 (2013): 3-15. https://doi.org/10.2486/indhealth.2012$\underline{0089}$

[16] Amin, Bokhori Md, and Abdul Halim Abdul Majid. "A study relationship work environment and employee performance on manufacturing sector in Penang, Malaysia." Journal of Advanced Research in Social and Behavioural Sciences 8, no. 1 (2017): 16-22.

[17] Rowlinson, Steve, Andrea YunyanJia, Baizhan Li, and Carrie ChuanjingJu. "Management of climatic heat stress risk in construction: a review of practices, methodologies, and future research." Accident Analysis \& Prevention 66 (2014): 187-198. https://doi.org/10.1016/j.aap.2013.08.011

[18] Chan, Albert PC, Michael CH Yam, Joanne WY Chung, and Wen Yi. "Developing a heat stress model for construction workers." Journal of Facilities Management (2012). https://doi.org/10.1108/14725961211200405

[19] Budd, Grahame M. "Wet-bulb globe temperature (WBGT)-its history and its limitations." Journal of Science and Medicine in Sport 11, no. 1 (2008): 20-32. https://doi.org/10.1016/i.jsams.2007.07.003

[20] Miller, Veronica S., and Graham P. Bates. "The thermal work limit is a simple reliable heat index for the protection of workers in thermally stressful environments." Annals of occupational hygiene 51, no. 6 (2007): 553-561.

[21] Malchaire, J. B. M. "Occupational heat stress assessment by the Predicted Heat Strain model." Industrial health 44, no. 3 (2006): 380-387. https://doi.org/10.2486/indhealth.44.380

[22] Hussin, A., E. Salleh, H. Y. Chan, and S. Mat. "The reliability of Predicted Mean Vote model predictions in an airconditioned mosque during daily prayer times in Malaysia." Architectural Science Review 58, no. 1 (2015): 67-76. https://doi.org/10.1080/00038628.2014.976538

[23] Somanathan, Eswaran, Rohini Somanathan, Anant Sudarshan, and Meenu Tewari. "The impact of temperature on productivity and labor supply: Evidence from Indian manufacturing." Journal of Political Economy 129, no. 6 (2021): 1797-1827. https://doi.org/10.1086/713733

[24] Kjellstrom, Tord, R. Sari Kovats, Simon J. Lloyd, Tom Holt, and Richard SJ Tol. "The direct impact of climate change on regional labor productivity." Archives of Environmental \& Occupational Health 64, no. 4 (2009): $217-227$. https://doi.org/10.1080/19338240903352776

[25] Venugopal, Vidhya, Jeremiah S. Chinnadurai, Rebekah Al Lucas, and Tord Kjellstrom. "Occupational heat stress profiles in selected workplaces in India." International journal of environmental research and public health 13 , no. 1 (2016): 89. https://doi.org/10.3390/ijerph13010089

[26] Chinnadurai, Jeremiah, Vidhya Venugopal, P. Kumaravel, and R. Paramesh. "Influence of occupational heat stress on labour productivity-a case study from Chennai, India." International Journal of Productivity and Performance Management (2016). https://doi.org/10.1108/IJPPM-08-2014-0121

[27] Sett, Moumita, and Subhashis Sahu. "Effects of occupational heat exposure on female brick workers in West Bengal, India." Global health action 7, no. 1 (2014): 21923. https://doi.org/10.3402/gha.v7.21923

[28] Kuklane, Kalev, Karin Lundgren, Tord Kjellstrom, Vidhya Venogopal, F. Fan, and George Havenith. "Insulation of traditional Indian clothing: estimation of climate change impact on productivity from PHS (predicted heat strain) model." In CIB W099 International Conference on Achieving Sustainable Construction Health and Safety, Lund University, Lund, Sweden, 2Á3 June. 2014.

[29] Yi, Wen, and Albert PC Chan. "Effects of heat stress on construction labor productivity in Hong Kong: a case study of rebar workers." International journal of environmental research and public health 14, no. 9 (2017): 1055. https://doi.org/10.3390/ijerph14091055

[30] Li, Xiaodong, Kwan Hang Chow, Yimin Zhu, and Ying Lin. "Evaluating the impacts of high-temperature outdoor working environments on construction labor productivity in China: A case study of rebar workers." Building and environment 95 (2016): 42-52. https://doi.org/10.1016/j.buildenv.2015.09.005

[31] Yang, Yang, Chan Allbert Ping. "Role of work uniform in alleviating perceptual strain among construction workers." Industrial health 55, no. 1 (2017): 76-86. https://doi.org/10.2486/indhealth.2016-0023

[32] Hajizadeh, Roohalah, Farideh Golbabaei, Mohammad Reza Monazzam, Somayeh Farhang-Dehghan, and Esmail Ezadi-Navan. "Productivity loss from occupational exposure to heat stress: a case study in brick workshops/QomIran." International Journal of Occupational Hygiene 6, no. 3 (2014): 143-148. 
[33] Al-Bouwarthan, Mohammed, Margaret M. Quinn, David Kriebel, and David H. Wegman. "Assessment of heat stress exposure among construction workers in the hot desert climate of Saudi Arabia." Annals of work exposures and health 63, no. 5 (2019): 505-520. https://doi.org/10.1093/annweh/wxz033

[34] Dutta, Priya, Ajit Rajiva, Dileep Andhare, Gulrez Shah Azhar, Abhiyant Tiwari, Perry Sheffield, and Climate Study Group. "Perceived heat stress and health effects on construction workers." Indian journal of occupational and environmental medicine 19, no. 3 (2015): 151. https://doi.org/10.4103/0019-5278.174002

[35] Bates, Graham P., and John Schneider. "Hydration status and physiological workload of UAE construction workers: A prospective longitudinal observational study." Journal of occupational medicine and toxicology 3, no. 1 (2008): 110. https://doi.org/10.1186/1745-6673-3-21

[36] Zhao, Jing, Neng Zhu, and Shilei Lu. "Productivity model in hot and humid environment based on heat tolerance time analysis." Building and environment 44, no. $11 \quad$ (2009): 2202-2207. https://doi.org/10.1016/i.buildenv.2009.01.003

[37] El-Shafei, Dalia A., Sarah A. Bolbol, Marwa B. Awad Allah, and Amira E. Abdelsalam. "Exertional heat illness: Knowledge and behavior among construction workers." Environmental Science and Pollution Research 25, no. 32 (2018): 32269-32276. https://doi.org/10.1007/s11356-018-3211-8

[38] Maiti, Rina. "Workload assessment in building construction related activities in India." Applied ergonomics 39 , no. 6 (2008): 754-765. https://doi.org/10.1016/j.apergo.2007.11.010

[39] Montazer, Saideh, Ali Asghar Farshad, Mohammad Reza Monazzam, Meysam Eyvazlou, Ali Akbar Sabour Yaraghi, and Roksana Mirkazemi. "Assessment of construction workers' hydration status using urine specific gravity." International journal of occupational medicine and environmental health 26, no. 5 (2013): $762-769$. https://doi.org/10.2478/s13382-013-0143-x

[40] Brake, D. J., and G. P. Bates. "Fluid losses and hydration status of industrial workers under thermal stress working extended shifts." Occupational and environmental medicine 60, no. 2 (2003): 90-96. https://doi.org/10.1136/oem.60.2.90

[41] Farshad, Aliasghar, Saideh Montazer, Mohammad Reza Monazzam, Meysam Eyvazlou, and Roksana Mirkazemi. "Heat stress level among construction workers." Iranian journal of public health 43, no. 4 (2014): 492.

[42] Morioka, Ikuharu, Nobuyuki Miyai, and Kazuhisa Miyashita. "Hot environment and health problems of outdoor workers at a construction site." Industrial health 44, no. 3 (2006): $474-480$. https://doi.org/10.2486/indhealth.44.474

[43] Yoopat, Pongjan, Pornkamon Toicharoen, Thirayudh Glinsukon, Kamiel Vanwonterghem, and Veikko Louhevaara. "Ergonomics in practice: physical workload and heat stress in Thailand." International journal of occupational safety and ergonomics 8, no. 1 (2002): 83-93. https://doi.org/10.1080/10803548.2002.11076516

[44] Ismail, Ahmad Rasdan, Norfadzilah Jusoh, Mohd Amin Mahd Asri, Raemy Md Zein, and Ismail Abdul Rahman. "Experimental Investigation of Workers Physiology under Tropical Climate in Construction Industries." Journal of Advanced Research in Fluid Mechanics and Thermal Sciences 78, no. 1 (2021): 35-47. https://doi.org/10.37934/arfmts.78.1.3547

[45] Inaba, Ryoichi, and Seyed Mohammad Mirbod. "Comparison of subjective symptoms and hot prevention measures in summer between traffic control workers and construction workers in Japan." Industrial health 45, no. 1 (2007): 91-99. https://doi.org/10.2486/indhealth.45.91 